\title{
Corrosion Study in Reinforced Concrete Made with Mine Waste as Mineral Additive
}

\author{
V. Volpi-León ${ }^{1,2}$, L. D. López-Léon ${ }^{1, *}, J$. Hernández-Ávila ${ }^{1}$, M. A. Baltazar-Zamora ${ }^{3}$, \\ F. J. Olguín-Coca ${ }^{1}$, A. L. López-León ${ }^{4}$ \\ ${ }^{1}$ Universidad Autónoma del Estado de Hidalgo, Carr. Pachuca- Tulancingo Km 4.5, Colonia \\ Carboneras, Mineral de la Reforma, Hidalgo. C.P. 42184, México. \\ ${ }^{2}$ Benemérita Universidad Autónoma de Puebla, Boulervard Valsequillo s/n, San Manuel, Puebla de \\ Zaragoza, Puebla. C.P. 72550, México. \\ ${ }^{3}$ Facultad de Ingeniería Civil - Xalapa, Universidad Veracruzana, Circ. G. Aguirre Beltrán S/N, Lomas \\ del Estadio, Xalapa, Veracruz, México, CP 91000, México. \\ ${ }^{4}$ Universidad Autónoma de Ciudad Juárez, Avenida del Charro 450 Norte, Colonia Partido Romero, \\ Cd. Juárez, Chihuahua. C.P. 32310, México. \\ *E-mail: luis_lopez@uaeh.edu.mx
}

doi: $10.20964 / 2017.01 .08$

Received: 23 September 2016 / Accepted: 7 November 2016 / Published: 12 December 2016

\begin{abstract}
This work studies an alternative to reuse mine waste materials in reinforced concrete. It pretends to determinate experimental parameters of corrosion resistance in different systems of concrete assesed, (with 5\%,10\% y 15\% recycled material instead of cement Portland) in comparison to conventional reinforced concrete. Specimens of concrete were exposed in a corrosive environment using a salt spray chamber. At the moment of assesing of the steel-concrete system in relation to exhibition time were used techniques half-cell potential and electrochemical impedance. It is worth mentioning that the halfcell potential indicates specimens with mine waste material does not suffer a significante change in comparison to conventional concrete system in relation a monitoring time. The results obtained by Electrochemical Impedance Spectroscopy technique show systems with mine waste material presents a slight diminish in the values of corrosion resistance and the total impedances does not show a significant change between to conventional concrete and a specimen with $10 \%$ of mine waste material.
\end{abstract}

Keywords: Corrosion, concrete, mine waste, electrochemical impedance, half-cell potential.

\section{$\underline{\text { FULL TEXT }}$}

(C) 2017 The Authors. Published by ESG (www.electrochemsci.org). This article is an open access article distributed under the terms and conditions of the Creative Commons Attribution license (http://creativecommons.org/licenses/by/4.0/). 